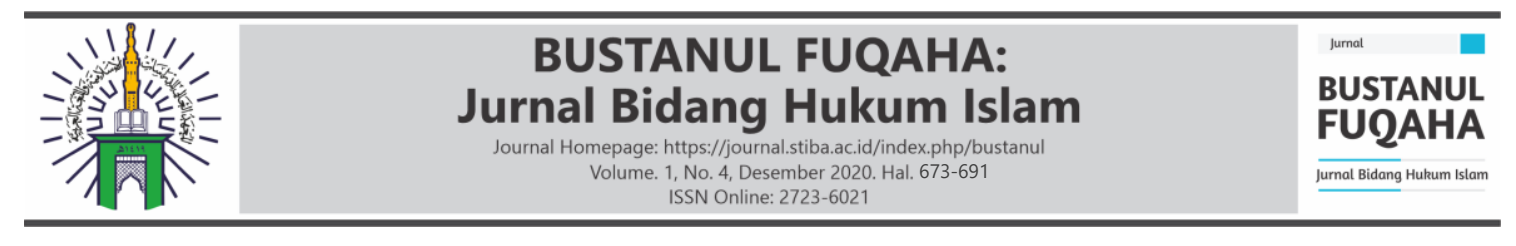

\title{
TABUNGAN EMAS DALAM TINJAUAN HUKUM ISLAM (STUDI KASUS DI PEGADAIAN SYARIAH CABANG PINRANG)
}

\author{
Khaerul Aqbar \\ Sekolah Tinggi Ilmu Islam dan Bahasa Arab (STIBA) Makassar \\ Email:khaerul@ stiba.ac.id \\ Aswar \\ Sekolah Tinggi Ilmu Islam dan Bahasa Arab (STIBA) Makassar \\ Email: aswar@stiba.ac.id \\ Muh. Sepriadi Sakti \\ Sekolah Tinggi Ilmu Islam dan Bahasa Arab (STIBA) Makassar \\ Email: saktiaone11@gmail.com
}

\begin{abstract}
Keywords :
ABSTRACT

Gold Saving, Sharia Pawnshop, This study aimed to determine the practice of product contracts and Islamic Perspective a review of Islamic law on gold savings products in Sharia pawnshops. The research method used a field research approach (filed research) which was qualitative descriptive, and data collection was obtained through observation, interviews, and library research (library research), and the research locus was the Syariah Pegadaian of Pinrang. The research results found that; First, regarding the practice, Syariah Pegadaian of Pinrang provides many facilities for customers who want to start investing in gold. In addition, Pegadaian Syariah also offers products in the form of gold savings, which is a gold buying and selling service with deposit facilities. As for the process of selling gold, it is carried out in two ways namely by reselling it if the customer wants cash and printing if the customer wants it in the form of gold bullion. Second, the gold savings scheme in sharia pawnshops is a problematic contract because one of the contracts has an element of usury, to be precise in the murabaha contract, where scholars have different opinions about its permissibility. Most scholars agree on the prohibition (because some scholars from syafi'iyyah and malikiyyah argue that gold is included as saman (price, means of payment, money) which cannot be exchanged in installments because it causes usury and must be done in cash at the time of the contract.
\end{abstract}

Kata kunci : ABSTRAK

Tabungan Emas, Pegadaian Syariah, Perspektif Islam
Penelitian bertujuan untuk mengetahui praktik akad produk dan tinjauan hukum Islam terhadap produk tabungan emas di Pegadaian Syariah. Metode penelitian menggunakan pendekatan penelitian lapangan (field research) yang bersifat deskriptif kualitatif, dan pengumpulan data diperoleh melalui observasi, wawancara dan studi kepustakaan (library research), serta lokus penelitian dilaksanakan di Pegadaian Syariah Cabang Pinrang. Hasil penelitian ditemukan bahwa; Pertama, mengenai praktiknya pihak Pegadaian Syariah Cabang Pinrang memberikan banyak kemudahan bagi nasabah yang ingin memulai untuk berivestasi emas. Selain itu, Pegadaian Syariah juga menawarkan produk berupa tabungan emas, 


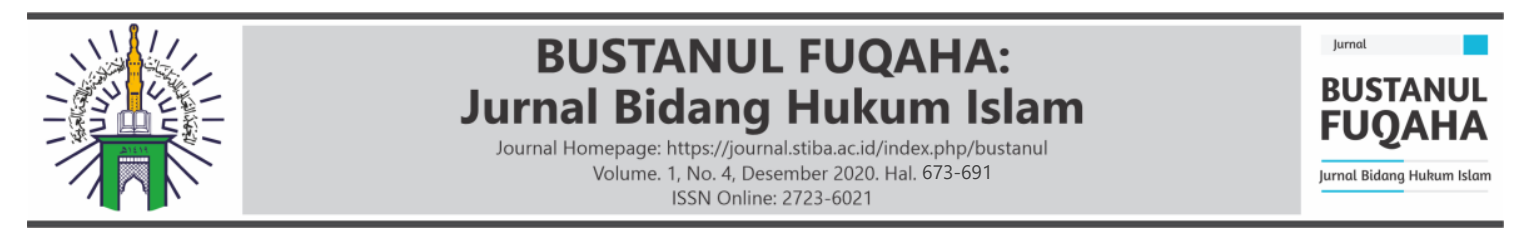

\begin{tabular}{l}
\hline yaitu layanan jual beli emas dengan fasilitas titipan. Adapun untuk \\
proses pencairan (menjual) emas dilakukan dengan dua cara yaitu \\
dengan jual kembali jika nasabah menghendaki uang tunai dan \\
pencetakan jika nasabah menghendaki dalam bentuk emas batangan. \\
Kedua, skema tabungan emas di Pegadaian Syariah termasuk akad \\
bermasalah karena salah satu akadnya terdapat unsur riba, tepatnya \\
pada akad murabahah, di mana ulama berbeda pendapat tentang \\
kebolehannya. Jumhur ulama sepakat akan keharamannya (karena \\
sebagian ulama dari Syafi'iyyah dan Malikiyyah dengan dalil bahwa \\
emas termasuk saman (harga, alat pembayaran, uang) yang tidak \\
boleh dipertukarkan secara angsuran, karena itu menyebabkan riba \\
dan harus dilakukan secara tunai pada saat akad terjadi.
\end{tabular}

\section{PENDAHULUAN}

Islam adalah agama yang sempurna. Agama rahmatan lil 'àlamīn dan dinamis, didalamnya mengatur seluruh sisi kehidupan manusia, baik perekonomian, sosial, politik dan sebagainya. Di mana perbedaan Islam dengan materialisme adalah bahwa Islam tidak pernah memisahkan ekonomi dan etika, Islam juga tidak memisahkan agama dengan negara, Islam juga berbeda dengan konsep kapitalisme yang memisahkan akhlak dengan ekonomi, dimana dalam konsep ekonomi syariah tidak hanya mengkaji individu sebagai makhluk sosial, sebagaimana yang menjadi kajian ekonomi barat, tetapi lebih dari itu. Konsep ekonomi syariah juga menempatkan individu sebagai makhluk yang mempunyai potensi religius. Oleh sebab itu, dalam pemenuhan kebutuhannya atau aktivitas ekonomi lainnya, ekonomi syariah menempatkan nilai-nilai Islam sebagai dasar pijakannya. Berbeda dengan konsep ekonomi barat yang menempatkan kepentingan individu sebagai landasannya.

Secara logis, ekonomi Islam dapat menjadi ekonomi alternatif dalam menghadapi dikotomi ekonomi kapitalis dan ekonomi sosialis, yang pada saat bersamaan mulai dikritisi kelemahannya. Sedangkan secara estetika, ekonomi Islam telah melahirkan kekuatan ekonomi yang menjaga keseimbangan dan keselarasan sosial dalam harmoni kehidupan, pembangunan ekonomi yang berkeadilan dan tidak merusak tatanan dan harmoni kehidupan semesta. Adapun secara etis, ekonomi Islam dibangun di atas landasan maqāsid al-syarī ah, yakni hif̧̣u al-dìn, hif̣u al-nafs, hif̧̣u al-nasl, hif̧̣u al-'aql, dan hif̣̌u al-māl ${ }^{1}$. Tujuan dari maqăsid al-syarī ah ini adalah tidak lain untuk kemaslahan hidup manusia itu sendiri, baik di dunia maupun di akhirat ${ }^{2}$.

Umat muslim, entah itu individu maupun kelompok dalam sektor ekonomi atau bisnis, di satu sisi diberi kebebasan untuk mencari keuntungan sebesar-besarnya. Namun, di sisi lain, ia terikat dengan iman dan etika sehingga ia tidak bebas mutlak dalam

${ }^{1}$ Iskandar, Azwar, and Khaerul Aqbar. "Kedudukan Ilmu Ekonomi Islam di Antara Ilmu Ekonomi dan Fikih Muamalah: Analisis Problematika Epistemologis." NUKHBATUL'ULUM: Jurnal Bidang Kajian Islam 5, no. 2 (2019): h. 102.

${ }^{2}$ Usman, M. H., Aswar, A., \& Irawan, A. W., "Syariat Islam dan Kemaslahatan Manusia di Era New Normal pada Kegiataan Keagamaan dan Pendidikan”, FENOMENA 12, no. 1 (2020): h. 90. 


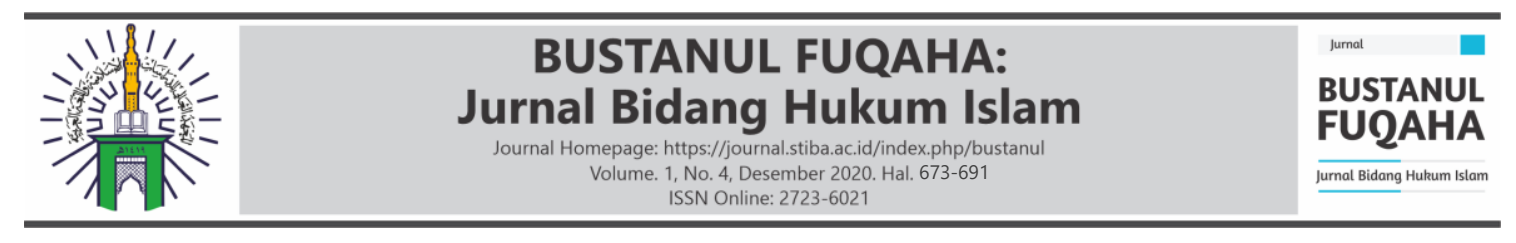

menginvestasikan modalnya atau membelanjakan hartanya. Alangkah baiknya sebagai muslim jika kita mengobarkan citra ekonomi Islam sebagai suatu cita-cita ilmu ekonomi. Nilai-nilai Islam tidak hanya berkaitan dengan proses ekonomi, tetapi juga berkaitan dengan tujuan dari kegiatan ekonomi. Islam menempatkan bahwa tujuan ekonomi tidak hanya kesejahteraan duniawi saja, tetapi juga untuk kepentingan yang lebih utama, kesejahteraan ukhrawi. Kemudian di antara aspek yang terpenting dalam perekonomian Islam adalah tentang teori tabungan dan atau investasi.

Kegiatan menabung merupakan hal yang penting dilakukan karena tabungan dapat digunakan sebagai bekal masa depan atau bertujuan untuk berjaga-jaga dalam kebutuhan yang penting di masa mendatang. Tabungan juga ikut mempengaruhi terhadap arus uang beredar terhadap investasi, produksi dan permintaan serta berperan dalam rangka stabilitas dan pembangunan ekonomi. Untuk itu, salah satu lembaga keuangan bukan bank di Indonesia yang mempunyai aktivitas pembiayaan masyarakat ialah Pegadaian Syariah. Kegiatannya baik bersifat produktif maupun konsumtif, dengan menggunakan hukum gadai. Prinsip transaksi yang digunakan oleh Pegadaian sama dengan prinsip pinjaman pada lembaga perbankan. Namun, yang membedakan ialah hukum yang digunakan yaitu hukum gadai ${ }^{3}$.

Hal mendasar yang menjadi tujuan dibentuknya Pegadaian Syariah yaitu menuntun masyarakat agar dapat menjalankan muamalah sesuai ajaran Islam dan terhindar dari transaksi riba. Kata syarí'ah dalam sebuah lembaga keuangan sudah menggambarkan akan hal tersebut. Namun, apa jadinya apabila salah satu produk mengantarkan nasabah ke perniagaan yang haram yang keluar dari sistem syarí'ah, seperti halnya dengan Tabungan emas. Tabungan emas Pegadaian Syariah adalah layanan pembelian dan penjualan emas dengan fasilitas titipan dengan harga yang terjangkau ${ }^{4}$. Di mana emas yang telah dibeli nasabah dengan menggunakan uang tidak langsung diterima ketika akad terjadi di tempat, akan tetapi, emas tersebut dititipkan dan terkonversi langsung dalam bentuk saldo.

Dari proses produk tabungan emas di atas dapat ditarik asumsi bahwa pembelian dengan cara menabung, pembayaran dengan menggunakan uang, dan emas tidak langsung diterima saat transaksi. Padahal sebagaimana yang diketahui, mayoritas fukaha bersepakat bahwa salah satu syarat jual beli emas dengan sesuatu yang sama 'illat-nya namun berbeda jenisnya seperti uang dalam Islam adalah adanya serah terima langsung ketika akad serta dilakukan secara tunai ${ }^{5}$. Hal ini sebagaimana yang terdapat dalam sebuah hadis, dari 'ubādah bin șāmit ra., bahwa Rasulullah saw. bersabda: h. 278.

${ }^{3}$ Ktut Silvanita Mangani, "Bank Dan Lembaga Keuangan Lain, (Jakarta : Penerbit Erlangga, 2009)

${ }^{4}$ Pegadaian Syariah, "Tabungan Emas", Situs Resmi Pegadaian Syariah. https://Pegadaiansyariah.co.id/tabungan-emas-2418 (12 Desember 2019).

${ }^{5} \mathrm{Nu}$ 'mān bin Mahmūd bin 'Abdillāh, jilāu u al- 'Aynayni fi muhā kamati al-Ahmadaini(t.t: Matba'ah al-Madanī, 1981), h. 630. 


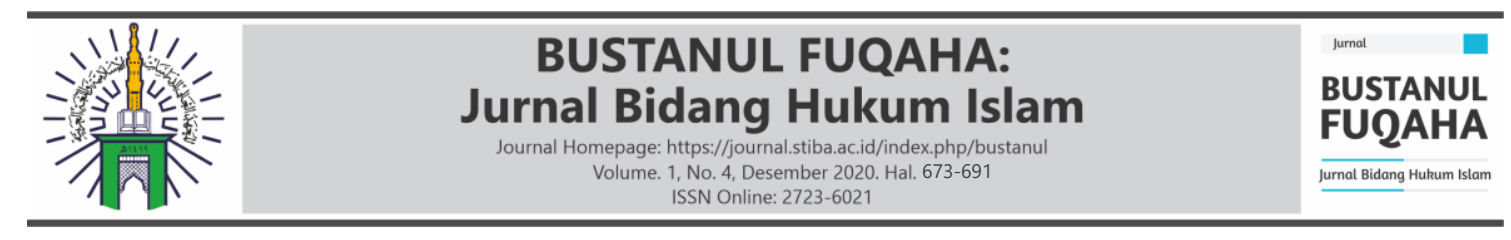

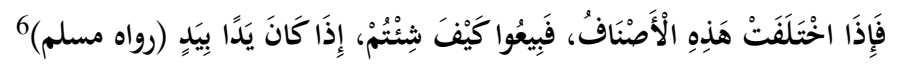

Artinya:

"Jika jenisnya berbeda, maka juallah sesuka kalian, selama dilakukan dari tangan ke tangan (kontan)."

Dari penjelasan yang telah dipaparkan di atas, maka diperlukan suatu kajian mendalam terhadap praktik tabungan emas yang terjadi pada sektor Pegadaian Syariah. Apakah semua prosedur atau mekanisme yang terjadi dalam lembaga keuangan ini telah benar-benar sesuai dengan syariat Islam atau tidak. Dengan demikian, penulis tertarik untuk mengadakan sebuah pengkajian terkait dengan tabungan Emas dalam tinjauan hukum Islam.

Berdasarkan hal tersebut, maka pokok dan substansi masalah yang didalami pada pengkajian ini adalah: (1) Bagaimana gambaran praktik/mekanisme tabungan emas di Pegadaian Syariah Cabang Pinrang?; (2) Bagaimana pandangan ulama fikih terhadap praktik tabungan emas di Pegadaian Syariah Cabang Pinrang dalam tinjauan hukum Islam?. Adapun tujuan pengkajian ini adalah untuk mengetahui gambaran praktik/mekanisme Tabungan Emas PT. Pegadaian Syariah Cabang Pinrang, serta mengetahui pandangan ulama fikih terhadap praktik tabungan emas tersebut.

Untuk itu, pengkajian ini diharapkan dapat dijadikan sumber pengetahuan, rujukan serta acuan bagi semua pihak yang ingin mendalami ilmu praktik fikih muamalah, khususnya yang berkenaan dengan tabungan emas. Selain itu, pengkajian ini dapat dijadikan sebagai tolak ukur atau pun data untuk pengkajian serupa ke depannya, dan dapat memberikan sumbangan pemikiran serta dapat menambah khazanah keilmuan dalam bidang perekonomian Islam. Adapun, secara praksis, pengkajian ini diharapkan bagi masyarakat, khususnya ekonom dan nasabah muslim, dapat menambah wawasan dan pengetahuan terkait tabungan emas dalam tinjauan hukum Islam.

Pengkajian ini menggunakan pendekatan deskriptif kualitatif. Tentang metode penelitian kualitatif, Creswell mendefinisikannya sebagai suatu pendekatan atau penelusuran untuk mengeksplorasi dan memahami suatu gejala sentral, dan untuk mengerti gejala sentral tersebut peneliti mewawancarai partisipan dengan mengajukan pertanyaan yang umum dan agak luas, serta informasi yang disampaikan oleh partisipan kemudian dikumpulkan, adapun informasi tersebut biasanya berupa kata atau teks, sehingga data yang berupa kata-kata atau teks tersebutlah yang kemudian dianalisis ${ }^{7}$.

Dalam pengkajian ini, penulis menggunakan dua jenis data yang disajikan sebagai sumber data, yaitu data primer melalui wawancara kepada Pegawai Pegadaian Syariah Cabang Pinrang dan data sekunder yang diperoleh dari dokumen-dokumen,

${ }^{6}$ Muslim bin al-Hajjāj Abu al-Hasan al-Qusyairi al-Naisābūri, șah̄̄h Muslim (Bairut:Dār Ihyā alTurāś al-'Arabī, t.th.), h. 1121.

${ }^{7}$ Conny R. Semiawan, Metode Penelitian Kualitatif Jenis, Karasteristik dan Keunggulannya (Cikarang:Grasindo,2010), h.7. 


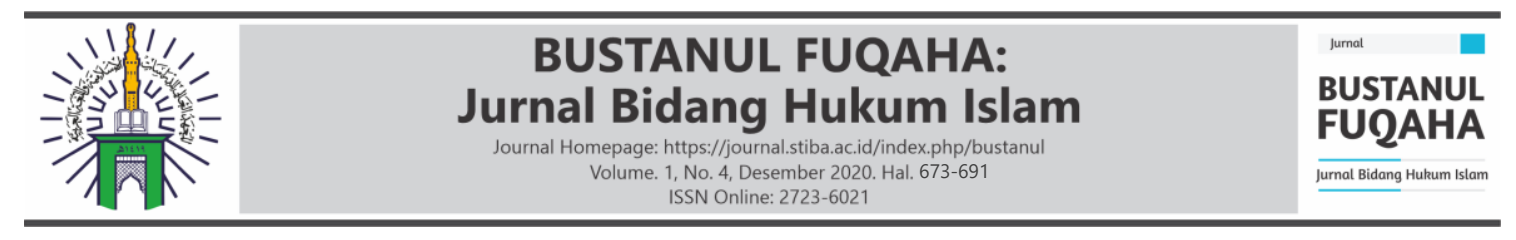

buku-buku, karya ilmiah, sumber internet, dan sebagainya yang dapat memperkaya data primer $^{8}$. Penulis juga menggunakan metode wawancara, studi pustaka, dan observasi dengan pekerja muslim yang ada di kantor Pegadaian Syariah Cabang Pinrang.

Selanjutnya, dalam melihat aspek kebaruan pengkajian ini, maka terlebih dahulu dilakukan literatur review dengan melihat beberapa penelitian terdahulu ihwal kajian praktik jual-beli emas. Adapun beberapa di antaranya adalah penelitian yang dilakukan oleh: Pertama, Asriani dalam jurnalnya yang berjudul, "Investasi Emas Syariah Dalam Perspektif Hukum Islam"9. Di mana hasil dari penelitian tersebut adalah bahwa jual beli emas secara tidak tunai merupakan sebuah proses pemindahan hak milik berupa emas yang dianggap sebagai harta atau barang komoditas kepada pihak lain dengan menggunakan uang sebagai salah satu alat tukarnya yang dibayarkan secara berangsurangsur dengan tingkat harga atau angsuran sesuai dengan kesepakatan dan kerelaan kedua belah pihak saat melakukan akad. Penelitian ini mengutip Fatwa Dewan Syariah Nasional No. 77 tahun 2010 tentang jual beli emas secara tidak tunai, yang secara eksplisit membolehkan transaksi jual beli emas secara angsuran atau cicilan. Fatwa ini menjawab kebingungan masyarakat dan pihak lembaga keuangan akan diperbolehkan atau tidaknya transaksi jual beli emas secara tidak tunai.

Namun, dalam praktik yang diterapkan lembaga keuangan ini, khususnya Bank dan Pegadaian Syariah ditemui banyak terjadi penyimpangan. Bahkan akad yang ada di fatwa tersebut (rahn dan murâbahah) dianggap kurang sesuai oleh sebagian cendikiawan muslim. Adapun yang membedakan penelitian penulis dengan jurnal ini ialah dari metode penelitian, yang mana penelitian ini merupakan bentuk penelitian pustaka, sementara pengkajian penulis menggunakan metode penelitian lapangan (field research).

Kedua, penelitian yang disusun oleh Yuyun Anggraini yang berjudul, "Tinjauan Hukum Islam Terhadap Jual Beli Emas pada Sistem Tabungan Emas Pegadaian Syariah Cabang Cakranegara Mataram"10. Penelitian ini berfokus pada akad jual beli emas pada sistem Tabungan Emas di Pegadaian Syariah Cabang Cakranegara Mataram dalam Hukum Islam. Kesimpulan penelitian tersebut ialah ulama berbeda pendapat mengenai kebolehannya. Adapun yang membedakan penelitian ini dengan pengkajian penulis adalah mengenai fokus penelitian yaitu akad dalam tabungan emas dan lokus penelitiannya.

Ketiga, penelitian yang disusun oleh Siska Nurul Riziqitaniyah yang berjudul, “Tinjauan Hukum Islam Terhadap Produk Tabungan Emas di Pegadaian Syariah dan

${ }^{8}$ Suharsimi Arikonto, Prosedur Penelitian Suatu Pendekatan Praktik (Cet. XV; Jakarta: Rineka Cipta, 2010), h. 22.

${ }^{9}$ Asriani, "Investasi Emas Syariah Dalam Perpektif Hukum Islam." Al-'Adalah 7, no. 4 (Desember 2015): h. 855-866.

${ }^{10}$ Anggraini, Y. (2017). Tinjauan hukum Ilam terhadap jual beli emas pada sistem tabungan emas pegadaian syariah cabang Cakranegara Mataram (Doctoral dissertation, Universitas Islam Negeri Mataram). 


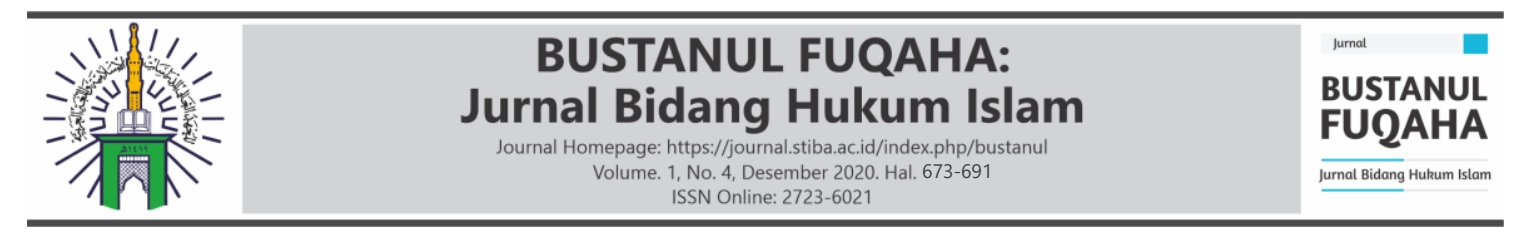

Pegadaian Konvensional (Studi komperatif)"11. Dalam produk tabungan emas Pegadaian Syariah ditemui menggunakan prinsip syariah yaitu murabahah dan wadiah dalam perjanjian atau akad yang digunakan dalam tabungan emas di Pegadaian Syariah Cabang Serang. Pegadaian konvensional umumnya dengan memberikan pinjaman sesuai dengan dasar hukum gadai. Adapun dalam produk tabungann emas Pegadaian konvensional tampak menggunakan prinsip jual beli dan titip emas. Penelitian ini termasuk ke dalam jenis penelitian lapangan (field research), bersifat deduktif dan analisis kualitatif, serta data dikumpulkan melalui dokumentasi, observasi, wawancara dan studi kepustakaan (library research). Hasil pengamat an penulis bahwa tabungan emas di Pegadaian Syariah dan Pegadaian konvensional adalah kurang adanya kejelasan antara barang yang di jual dan dititip dalam Pegadaian. Penelitian ini memiliki banyak persamaan dengan pengkajian penulis, namun, perbedaannya terletak pada lokus penelitiannya dalam mengkonfirmasi data terkait kajian tabungan emas.

\section{PEMBAHASAN}

\section{Gambaran Praktik dan Mekanisme Tabungan Emas PT. Pegadaian Syariah Cabang Pinrang}

Tabungan emas merupakan aktivitas jual beli emas dengan fasilitas titipan dan merupakan produk yang ditawarkan oleh Pegadaian Syariah Cabang Pinrang. Aktivitas tabungan emas inilah yang akan menjadi objek kajian agar proses praktik atau pun mekanismenya dapat ditelusuri dan diketahui dalam perspektif hukum Islam. Dalam rangka mengetahui hal tersebut, penulis melakukan observasi dan wawancara dari pegawai Pegadaian Syariah Pinrang sendiri. Adapun teknik wawancara yang digunakan adalah wawancara tidak terstruktur, di mana penulis bebas menentukan fokus masalah wawancara mengikuti dan menyesuaikan dengan situasi dan kondisi informan.

Dari wawancara tersebut, dapat diketahui bahwa tabungan emas di Pegadaian Syariah Cabang Pinrang adalah layanan pembelian dan penjualan emas dengan fasilitas titipan dengan harga yang terjangkau. Layanan ini memberikan kemudahan kepada masyarakat untuk berinvestasi emas. Berdasarkan pernyataan informan berinisial AR selaku pengelola unit di Pegadaian Syariah Cabang Pinrang, menuturkan bahwa: "Maksud dari pengertian di atas adalah nasabah sudah bisa berinvestasi dengan membeli emas minimal $R p 10.000$ dan akan terkonversi langsung dalam bentuk Tabungan Emas, sehingga aman dan mudah dibawa ke manapun"12. Dalam wawancara beliau pula sedikit ditambahkannya tentang filosofi produk tabungan emas di Pegadaian Syariah Cabang Pinrang, yang mana beliau mengatakan: “Karena banyaknya masyarakat

\footnotetext{
${ }^{11}$ Siska Nurul Riziqitaniyah, "Tinjauan Hukum Islam Terhadap Produk Tabungan Emas di Pegadaian Syariah dan Pegadaian Konvensional (studi komperatif)", Penelitian, (Banten: Fakultas Syariah Universitas Islam Negeri Sultan Maulana Hasanuddin Banten, 2019.

${ }^{12}$ Annisha Resqia M,SE, Pengelola Unit Pegadaian Syaraih Cabang Pinrang, Wawancara, Pinrang, 10 April 2020.
} 


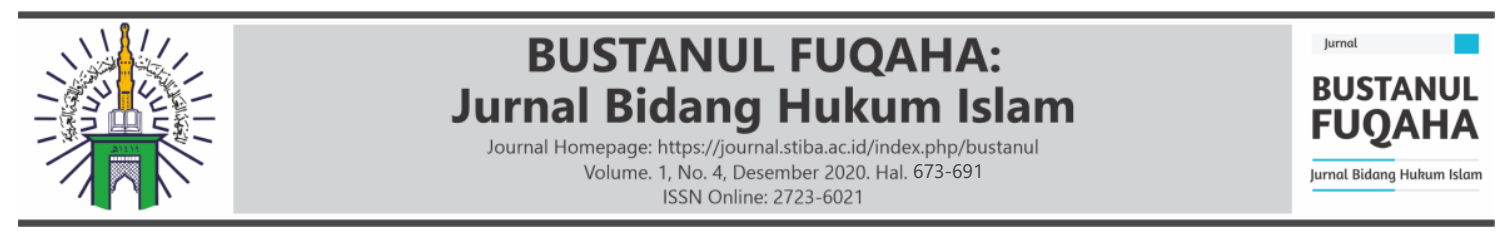

yang ingin berinvestasi emas tapi takut dengan keamanannya, sehingga Pegadaian menciptakan produk ini"13.

Sistem tabungan emas berbeda dengan sistem tabungan pada umumnya, karena tabungan emas lebih berfokus pada nominal saldo gram emasnya bukan nominal jumlah dana yang ditabungkan oleh nasabah. Adapun istilah tabungan emas hanyalah nama produk yang tujuannya untuk mempermudah pemasaran kepada masyarakat, serta mempermudah masyarakat untuk memiliki emas secara bertahap. Adapun tabungan emas pada dasarnya menggunakan sistem jual beli dan titip emas. Selanjutnya, prosedur tabungan emas yang dilakukan di Pegadaian Syariah Cabang Pinrang yaitu: ${ }^{14}$ (1) Siapkan syarat dan ketentuan yang diperlukan guna membuka rekening Tabungan Emas di Kantor Cabang Pegadaian; (2) Mengisi formulir pembukaan rekening serta membayar biaya administrasi sebesar Rp. 10.000,- dan biaya fasilitas titipan selama 12 bulan sebesar Rp. 30.000,-; (3) Setelah mengisi formulir dan membayar administrasi nasabah akan menerima buku Tabungan Emas dan dapat melakukan pembelian Tabungan Emas mulai dari 0.01 gram; (4) Apabila menghendaki fisik emas batangan, Anda dapat melakukan order cetak dengan pilihan keping (1gr, $2 \mathrm{gr}$, $5 \mathrm{gr}, 10 \mathrm{gr}, 25 \mathrm{gr}, 50 \mathrm{gr}$, dan $100 \mathrm{gr}$ ) dengan membayar biaya cetak sesuai dengan kepingan yang dipilih; (5) Transaksi pencetakan emas batangan, saat ini hanya dapat dilayani di Kantor Cabang tempat pembukaan rekening dengan menunjukan buku tabungan dan identitas diri yang asli; (6) Untuk informasi lebih lanjut bisa hubungi call center Pegadaian pada nomor yang tertera.

Terkait prosedur di atas, informan berinisial AR menambahkan bahwa "Seluruh prosedur tabungan emas dapat dilakukan dengan syarat nasabah membawa KTP dan mengisi formulir tabungan emas serta melakukan penyetoran pertama senilai Rp 50.000,-, dan untuk pembukaan awal hanya bisa dilakukan di Pegadaian khususnya Pegadaian Syariah. Untuk penyetoran selanjutnya bisa melalui ATM atau pun dengan menggunakan aplikasi Pegadaian Syariah"15.

\section{Bentuk Akad Jual Beli Emas pada Sistem Tabungan Emas}

Akad yang dilakukan adalah akad jual beli emas lalu dititipkan ke Pegadaian. Sebagai contoh nasabah yang akan membuka tabungan awal senilai satu gram, diharuskan menyetor dana sebesar satu juta rupiah. Informan berinisial AR menuturkan bahwa "Pihak Pegadaian tidak menyerahkan emas tapi hanya menerbitkan buku kepemilikan bahwa nasabah sudah memiliki emas 1 gram dan dititipkan di Pegadaian"16. Hal senada kembali ditegaskan oleh informan berinisial AR bahwa "Akad yang

${ }^{13}$ Annisha Resqia M,SE, Pengelola Unit Pegadaian Syaraih Cabang Pinrang, Wawancara, Pinrang, 19 April 2020.

${ }^{14} \mathrm{https}$ //www.Pegadaian.co.id/produk/tabungan-emas. Di akses tanggal 12 April 2020

${ }^{15}$ Annisha Resqia, Wawancara, Pinrang, 10 April 2020.

${ }^{16}$ Annisha Resqia, Wawancara, Pinrang, 10 April 2020. 


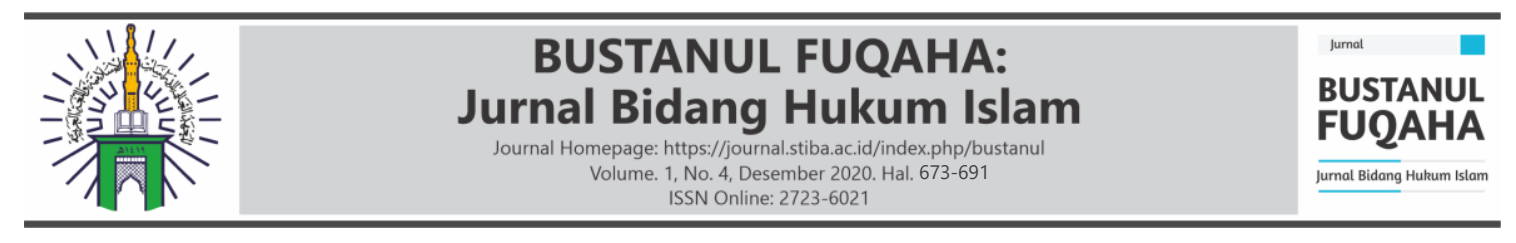

digunakan dalam tabungan ini yaitu akad jual beli murabahah dan wadiah, karena ada jual beli kemudian dititipkan"17.

Dengan demikian, bentuk akad yang digunakan dalam produk tabungan emas di Pegadaian Syariah Cabang Pinrang yaitu: Pertama, Akad Murabahah. Akad Murabahah merupakan akad antara pihak pertama (pegadaian) dengan pihak kedua (nasabah/pembeli) mengadakan akad jual beli, dengan syarat dan ketentuan dalam pasalpasal yang telah ditentukan dan menjadi kesepakatan antara pihak pertama dengan pihak kedua; Kedua, Akad Wadiah. Akad Wadiah merupakan akad/kesepakatan yang menyatakan bahwa sebelumnya para pihak telah sepakat untuk melakukan akad jual beli, dimana emas yang dibeli tidak diserahkan langsung melainkan dititipkan kepihak pertama dalam bentuk saldo. Atas penitipan tersebut para pihak mengadakan akad wadiah.

\section{Mekanisme Jual Beli Emas pada Sistem Tabungan Emas}

Emas mempunyai berbagai aspek yang menyentuh kebutuhan manusia. Selain karena nilai estetis yang tinggi, emas juga merupakan jenis investasi yang nilainnya stabil, likuid, dan aman secara riil. Oleh sebab itu, Pegadaian Syariah Cabang Pinrang menawarkan produk berupa tabungan emas. Tabungan emas merupakan layanan jual beli emas dengan fasilitas titipan. Dalam aplikasinya, mekanisme tabungan emas ini minimal melibatkan tiga pihak yaitu: pertama, Pegadaian selaku penjual dan penerima titipan; kedua, nasabah selaku pembeli; dan ketiga, supplier atau pihak yang diberi kuasa oleh Pegadaian untuk menjual barang. Secara praksis, mekanisme tabungan emas seperti yang disampaikan informan berinisial AR adalah bahwa: "Nasabah membayar sejumlah uang pada kasir dan menyerahkan buku Tabungan Emas kepada kasir, selanjutnya setelah diproses oleh kasir, emas yang dibeli langsung masuk ke buku Tabungan Emas" "18.

Dalam hal ini, nasabah selaku pembeli menabung (membeli) emas ke Pegadaian Syariah selaku penjual. Kemudian jumlah uang yang ditabung oleh nasabah akan dikonversikan ke dalam bentuk gram emas oleh Pegadaian sesuai dengan jumlah nominal yang ditabung dan tentunya sesuai dengan harga jual beli emas pada hari itu juga. Dari proses pembelian tersebut, maka nasabah akan mendapatkan beberapa gram emas yang tidak diserahkan langsung saat transaksi, melainkan diberikan dalam bentuk saldo gram emas yang tercatat dalam buku tabungan dan dititipkan di Pegadaian. Dengan kata lain, ketika nasabah menyerahkan uang, pihak Pegadaian tidak menyerahkan emas yang dibeli secara langsung, namun hanya menerbitkan surat bukti kepemilikan bahwa nasabah memiliki emas sejumlah yang dibeli dan dititipkan di Pegadaian.

Berikut ini dipaparkan beberapa ilustrasi proses tabungan emas di Pegadaian Syariah Cabang Pinrang;

\footnotetext{
${ }^{17}$ Annisha Resqia, Wawancara, Pinrang, 19 April 2020.

${ }^{18}$ Annisha Resqia, Wawancara, Pinrang, 10 April 2020.
} 


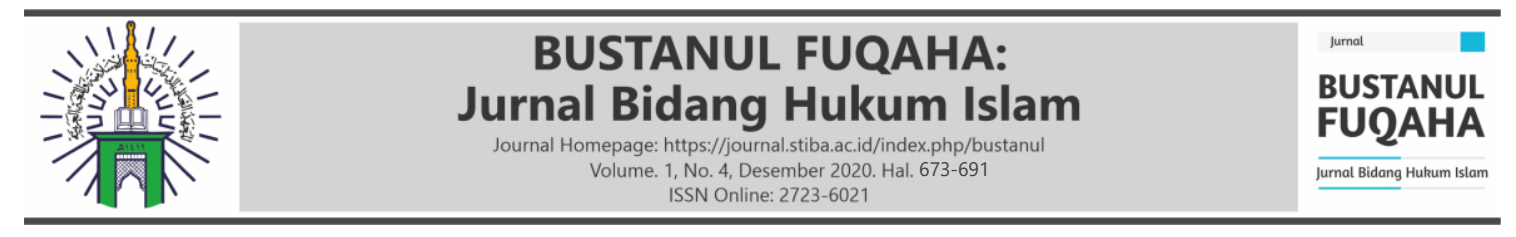

Tabel 1. Ilustrasi Pembelian Tabungan Emas

- Harga jual 0,01 gr. emas adalah Rp. 9.140,-. Si fulan datang ke Pegadaian dengan membawa uang sejumlah Rp.200.000,- untuk pembelian Tabungan Emas. Si fulan kemudian mengisi form pembelian emas sambil menunggu antrian. Setelah si fulan dipanggil, maka si fulan menyerahkan buku Tabungan Emas, form pembelian emas serta uang pembelian. Pembelian diproses oleh Pegadaian, sementara si fulan menunggu untuk dipanggil lagi. Setelah pemanggilan selanjutnya, Pegadaian memberikan buku Tabungan Emas dan form pembelian emas sebagai bukti pembelian. Pihak Pegadaian kemudian menerangkan bahwa dari pembelian Rp.200.000,- di dapatkan 0,2188 gr. emas. Di mana syarat dalam pembelian dikonversi menjadi emas sampai dengan 4 digit di belakang koma. Kemudian sisa dari selisihnya merupakan keuntungan dari Pegadaian (dikelola sebagai Dana Kepedulian Sosial atau Dana Kebajikan Umat.

Sumber: Harga jual emas Pegadaian per tanggal 23 Desember $2020^{19}$

Kemudian untuk proses pencairan (menjual) emas, maka saldo gram emas yang dimiliki oleh nasabah dijual kembali ke Pegadaian apabila menghendaki dalam bentuk uang tunai, tentunya dengan harga jual beli emas pada hari itu, tidak dengan berapa jumlah uang yang ditabungkan oleh nasabah. Hal tersebut disampaikan oleh informan berinisial AR bahwa "Untuk penjualan atau pencairan dalam bentuk uang itu, nasabah tinggal menyerahkan buku tabungan emas kepada kasir, menyebutkan berapa gram yang akan dijual dengan ketentuan saldo emas tersisa minimal 0,1 gram"20. Apabila nasabah menghendaki dalam bentuk emas batangan, maka hanya akan diminta biaya pencetakan saja.

Untuk lebih memahami lebih rinci dan konkrit, berikut ilustrasi penjualan dan pencetakan Tabungan Emas.

\section{Tabel 2. Ilustrasi Penjualan Tabungan Emas}

- Harga beli 0,01 gr. emas adalah Rp. 9.140,--

- Saldo tabungan A adalah 2 gram

- Saldo yang akan di jual si fulan adalah 1 gram

Si fulan datang ke Pegadaian untuk penjualan kembali Tabungan Emas. Si fulan kemudian mengisi form penjualan emas sambil menunggu antrian. Setelah si fulan dipanggil, maka si fulan menyerahkan buku Tabungan Emas dan form penjualan emas. Penjualan diproses oleh Pegadaian, sementara si fulan menunggu untuk dipanggil lagi. Setelah pemanggilan selanjutnya, Pegadaian memberikan buku Tabungan Emas dan form penjualan emas sebagai bukti penjualan serta uang

\footnotetext{
${ }^{19} \mathrm{https} / /$ www.pegadaian.co.id/produk/tabungan-emas (Diakses tanggal 23 Desember 2020)

${ }^{20}$ Annisha Resqia, Wawancara, Pinrang, 10 April 2020.
} 


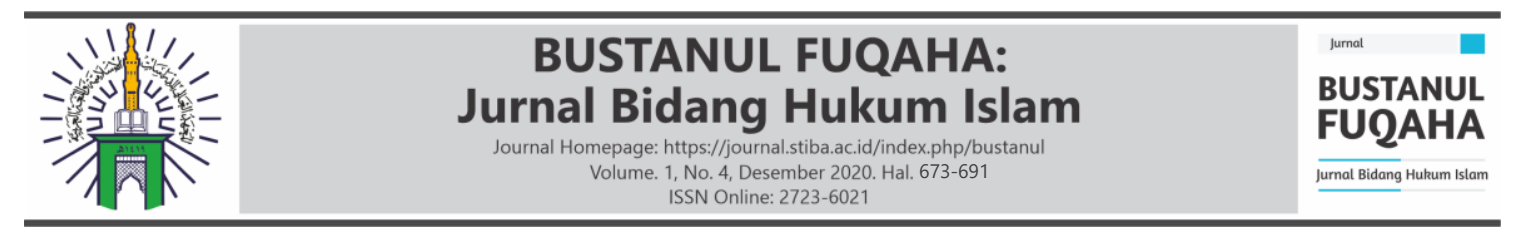

hasil penjualan sejumlah Rp. 914.000,-. Pihak Pegadaian kemudian menerangkan bahwa dari penjualan 1 gram emas adalah Rp. 914.000,- dan sisa saldo tabungan si fulan adalah 1 gram.

Sumber: Harga jual emas Pegadaian per tanggal 23 Desember $2020^{21}$

\section{Tabel 3. Ilustrasi Pencetakan Tabungan Emas}

- Saldo tabungan A adalah 6 gram

- Yang akan dicetak 5 gram

Si fulan datang ke Pegadaian untuk melakukan pencetakan Tabungan Emas. Si fulan kemudian mengisi form pencetakan emas sambil menunggu antrian. Setelah si fulan dipanggil, maka si fulan menyerahkan buku Tabungan Emas dan form pencetakan emas. Kemudian dalam buku rekening Tabungan Emas akan diproses oleh Pegadaian, untuk pengurangan saldo, sementara si fulan menunggu untuk dipanggil lagi.

Setelah pemanggilan selanjutnya, Pegadaian memberikan buku Tabungan Emas dan form pencetakan emas sebagai bukti pencetakan, serta pihak Pegadaian akan meminta biaya pencetakan sebesar Rp.127.000,- (biaya pencetakan tergantung dengan jumlah gram yang akan dicetak). Pihak Pegadaian kemudian menerangkan bahwa emas batangan yang diorder si fulan akan jadi atau datang sekitar 2 pekan kemudian. Apabila si fulan terlambat mengambil emas batangan yang telah diorder, maka si fulan dikenakan biaya keterlambatan pengambilan tersebut.

Dalam proses kinerja Pegadaian Syariah sendiri, tampak skema percetakan atau pengambilan barang fisik emas seperti gambar berikut ini; ${ }^{22}$

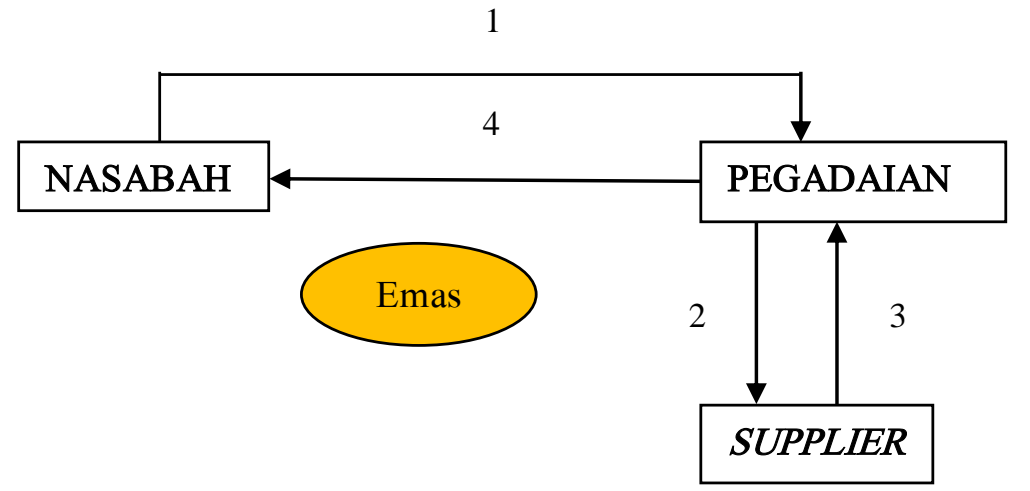

Gambar 1. Skema Percetakan/Pengambilan Fisik Emas

\footnotetext{
${ }^{21}$ https://www.pegadaian.co.id/produk/tabungan-emas (Diakses tanggal 23 Desember 2020)

${ }^{22}$ Anggraini, Y. (2017). Tinjauan hukum Ilam terhadap jual beli emas pada sistem tabungan emas pegadaian syariah cabang Cakranegara Mataram (Doctoral dissertation, Universitas Islam Negeri Mataram).
} 


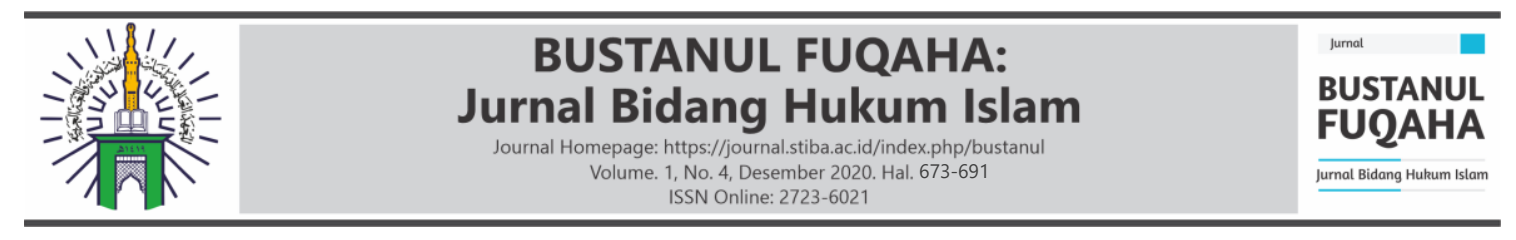

Keterangan:

1. Nasabah melakukan akad jual beli dengan Pegadaian, pembelian emas disesuaikan dengan harga jual beli emas pada hari itu. Pegadaian kemudian menerbitkan bukti pembelian atau kepemilikan emas dalam bentuk tabungan emas. Karena dalam hal ini, emas akan diambil di kemudian hari. Dengan demikian, terjadilah akad wadiah/penitipan, di mana jumlah gram emas dari hasil pembelian dititipkan dalam bentuk saldo.

2. Pegadaian mengorder emas yang dipesan oleh nasabah ke supplier. Dalam hal ini, Pegadaian akan mengorder emas ke supplier ketika nasabah ingin mencairkan saldo tabungan emas dalam bentuk emas batangan dengan nasabah akan diminta biaya percetakan.

3. Supplier mengirim emas batangan ke Pegadaian sesuai pesanan nasabah, dan tanggung jawab terhadap resiko barang telah berpindah ke Pegadaian.

4. Pihak Pedagaian menyerahkan emas batangan ke nasabah.

Dari keterangan di atas dapat di simpulkan bahwa pembelian tabungan emas ini terdiri dari dua akad transaksi yaitu: (1) Akad dari supplier kepada Pegadaian; dan (2) Akad dari Pegadaian kepada nasabah. Untuk alur nomor (1) terjadi dua akad yaitu akad jual beli dan wadiah, di mana setelah nasabah membeli emas, maka berapa jumlah gram emas yang dimiliki oleh nasabah kemudian dititipkan di Pegadaian dalam bentuk saldo. Konsep tabungan emas Pegadaian mengacu kepada emas batangan 1 kg, jadi Pegadaian terlebih dahulu menyediakan stok emas batangan dengan jumlah tertentu. Dalam wawancara dengan informan berinisial AR, beliau mengatakan bahwa "Fisik emas pada dasarnya tidak tersedia di Pegadaian, akan tetapi bukti kepemilikan telah tertera di buku tabungan sesuai besar gram yang dimiliki nasabah. Apabila nasabah ingin mengambil emas secara fisik, wajib melakukan pemesanan terlebih dahulu. Tetapi apabila nasabah hanya ingin mengambil tabungan emas dalam bentuk uang, maka bisa langsung menjual emas sesuai harga emas pada saat it ${ }^{\prime \prime 23}$. Adapun alur penyimpanan dan pengambilan tabungan emas disajikan berikut ini; ${ }^{24}$

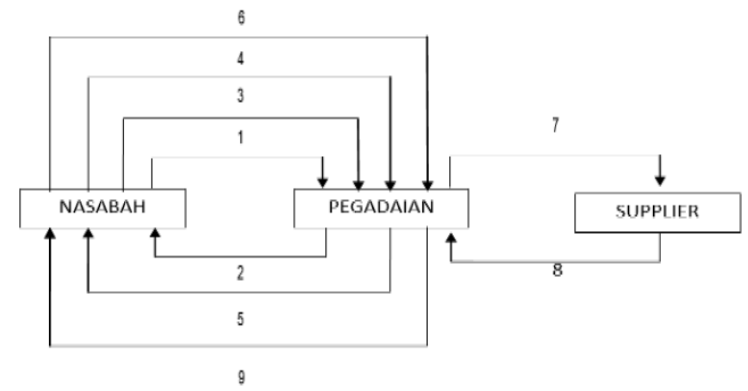

Gambar 2. Alur Penyimpanan dan Pengambilan Tabungan Emas

\footnotetext{
${ }^{23}$ Annisha Resqia, Wawancara, Pinrang, 19 April 2020.

${ }^{24}$ Anggraini, Y. (2017). Tinjauan hukum Ilam terhadap jual beli emas pada sistem tabungan emas pegadaian syariah cabang Cakranegara Mataram (Doctoral dissertation, Universitas Islam Negeri Mataram).
} 


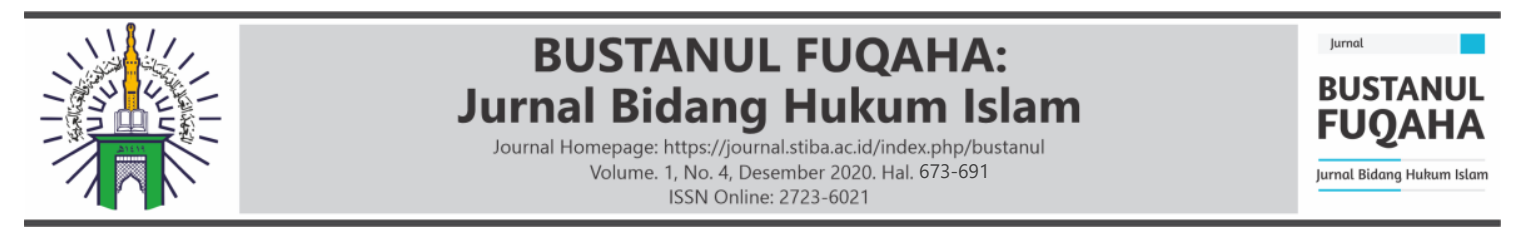

Keterangan:

1. Nasabah datang ke Pegadaian untuk membuat rekening Tabungan Emas (sesuai dengan prosedur pembuatan rekening).

2. Pegadaian menyerahkan buku rekening tabungan emas kepada nasabah.

3. Nasabah datang membeli emas di Pegadaian sekaligus melakukan penitipan saldo tabungan setelah uang nasabah dikonversikan ke dalam gram emas.

4. Nasabah datang untuk menjual kembali saldo tabungan emas (pencairan dalam bentuk uang tunai).

5. Pegadaian menyerahkan uang tunai hasil penjualan kembali ke nasabah.

6. Nasabah datang untuk mencairkan saldo tabungan dalam bentuk emas batangan, kemudian nasabah akan diminta biaya cetak saja.

7. Pegadaian mengorder emas batangan sesuai pesanan nasabah ke supplier.

8. Supplier mengirim emas batangan yang telah diorder ke Pegadaian.

9. Pegadaian menyerahkan emas batangan ke nasabah.

\section{Biaya-biaya dalam Tabungan Emas}

Biaya-biaya dalam jual beli dan titip emas atau tabungan emas selain biaya fasilitas titipan, ada pula biaya administrasi sebesar Rp. 30.000,- sebagaimana yang dikatakan oleh informan berinisial AR dalam wawancara bahwa "Biaya yang dikeluarkan dalam tabungan emas yaitu administrasi Rp. 30.000,- per tahun" ${ }^{25}$. Selain itu, biaya-biaya yang ada dalam transaksi tabungan emas dapat berupa biaya pembukaan rekening dan biaya transaksi tabungan emas serta biaya cetak emas batangan ${ }^{26}$.

\section{Pandangan Ulama Fikih Terhadap Praktik Tabungan Emas di Pegadaian Syariah Cabang Pinrang dalam Tinjauan Hukum Islam}

Pegadaian Syariah sebagai lembaga formal yang berbentuk unit dari Perum Pegadaian di Indonesia yang bertugas menyalurkan pembiayaan dalam bentuk pinjaman kepada masyarakat berlandasarkan hukum gadai syariah. Dewasa ini juga melakukan aktivitas jual beli emas dengan fasilitas titipan yang disebut dengan Tabungan Emas yang penyerahan barangnya tidak diserahkan saat terjadinya transaksi.

\section{Hukum Jual Beli Emas/Murabahah Emas}

Secara umum, pedoman jual-beli emas tersirat dalam sebuah hadis, dari Ubadah bin șamit r.a., bahwa Nabi saw.:

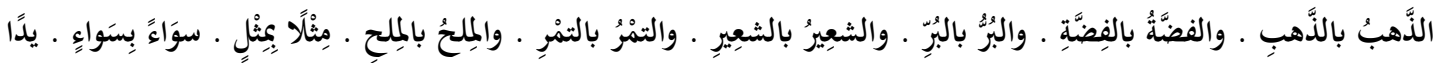

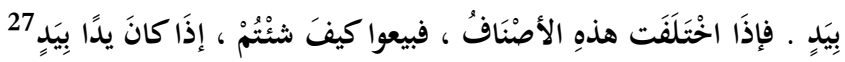

\footnotetext{
${ }^{25}$ Annisha Resqia, Wawancara, Pinrang, 19 April 2020.

${ }^{26} \mathrm{https}$ ///www.Pegadaian.co.id/produk/tabungan-emas 14 April 2020

${ }^{27}$ Muslim bin al-Hajjāj Abu al-Hasan al-Qusyairi al-Naisābūri, Șahīh Muslim (Bairut:Dār Ihyā alTurās al-'Arabī, t.th.), h. 1121.
} 


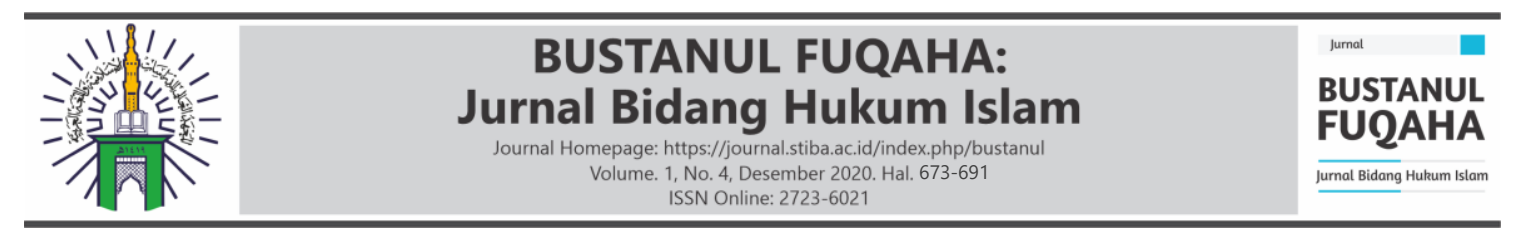

Artinya:

“Emas dengan emas, perak dengan perak, burr dengan burr, sya'ir dengan sya'ir, tamr dengan tamr, garam dengan garam, kadarnya harus semisal dan sama, harus dari tangan ke tangan (kontan). Jika jenisnya berbeda, maka juallah sesuka kalian, selama dilakukan dari tangan ke tangan (kontan)" (H.R. Al Bukhari, Muslim no. 1587, dan ini adalah lafadz Muslim)".

Sebelum membahas hukum jual-beli emas, ada beberapa bahasan yang perlu diketahui yaitu sebagai berikut:

\section{Emas sebagai Komoditi ribawi}

Sumber pokok penentuan komoditi ribawi adalah hadis Ubadah bin șamit yang telah dibawakan, disana disebutkan enam komoditi yaitu emas, perak, burr, sya ī $r$, tamr, garam. Enam komoditi ini dikelompokkan oleh para ulama menjadi 2 kelompok, yaitu Alat tukar yaitu kelompok emas-pesar dan makanan yaitu kelompok selain emas-perak diantaranya: burr, sya $\bar{\imath} r$, tamr, garam. Untuk komoditi emas dan perak, maka terdapat perbedaan pendapat para ulama tentang 'illat -nya. Pendapat pertama: 'illat riba untuk emas dan perak adalah satuan berat dan sejenis. Ini merupakan pendapat mazhab Hanafi dan Hanbali. Namun, disisi lain salah satu ulama dari Hanaabilah yaitu Abdullaah alKharqii dalam bukunya yang di syarh oleh 'Abdul Kariim al-Khudhair berpendapat bahwa hukum membeli emas dengan menggunakan uang wajib didalamnya terjadi serah terima dan haramnya cicilan dalam akad ini.

Pendapat kedua: 'illat riba untuk emas dan perak adalah ghalabah al-siamaniyah (dominasi sebagai alat tukar). Pendapat ini merupakan mazhab Syafi'i dan Maliki ${ }^{28}$. Pendapat ketiga: 'illat riba untuk emas dan perak adalah muțlaq samaniyah (mutlak sebagai alat tukar) atau qiyamul asyyā' (pengukur nilai harga). Pendapat ini didukung oleh Al-Syīrāzi (ulama mazhab Syafii, wafat th. $476 \mathrm{H}$ ) dan sebagian ulama mazhab Maliki $^{29}$. Dalil dari pendapat yang mengatakan 'illat emas dan perak adalah mut laq śamaniyah merupakan pendapat yang terkuat dan didukung oleh seluruh lembaga fatwa internasional.

Setelah memahami pemaparan sebelumnya, maka kita bisa mengambil kesimpulan bahwa uang adalah komoditi ribawi. Oleh karena uang termasuk alśamaniyah walaupun berbeda jenis dengan emas dan perak, sehingga ia di kiaskan dengan emas dan perak. Al-śaman dalam jual beli adalah alat tukar atau alat pembayaran dalam jual-beli. Dengan demikian, jelas bahwa uang termasuk śaman dan

${ }^{28}$ al- Mawardi, al- Hawi al- Kabir fi fiqh mazhab al-Imam al-Syafi'i, ( Cet.: I; Bairut: Dar al- Kutub al- 'Ilmiyyah, 1999M), h. 91. Muhammad bin 'Abdillah al- Kharsyi al- Maliki, Syarh Mukhtasar Khalil, (Bairut: Dar al- Fikr littiba'ah, t.th.), h. 56.

${ }^{29}$ Erwandi Tarmizi, Harta Haram Muamalat Kontmporer, h. 547. 


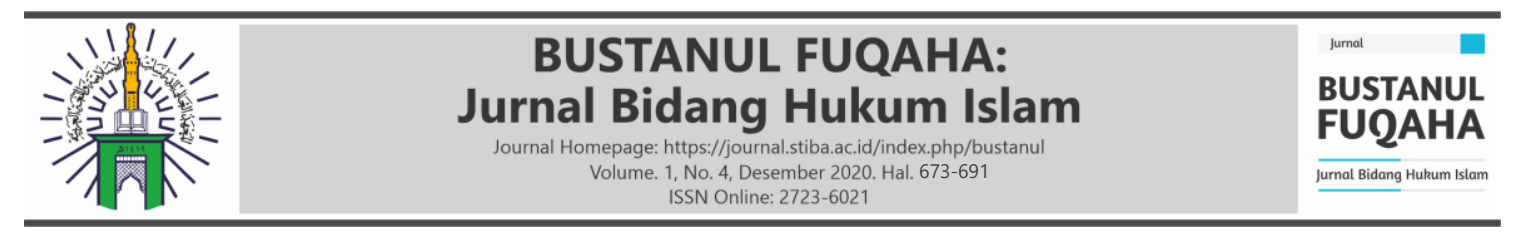

uang baik kertas ataupun logam adalah komoditi ribawi yang berlaku baginya aturanaturan jual-beli komoditi ribawi.

\section{Aturan dalam Jual-Beli Komoditi Ribawi}

Däbit ${ }^{30}$ pertama: Semua komoditi yang sama jenisnya dan illat-nya, maka dalam transaksinya disyaratkan dua syarat: sama nilainya dan al-taqābud (langsung serah terima di majelis akad atau kontan). Contohnya: barter emas dengan emas, barter perak dengan perak, barter uang dengan uang. Dāait kedua: Semua komoditi yang sama 'illatnya, namun berbeda jenisnya, maka dalam transaksinya disyaratkan satu syarat: altā qabud (langsung serah terima di majlis akad atau kontan).

Berdasarkan sabda Rasulullah saw.,

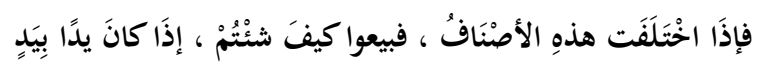

Artinya: “Jika jenisnya berbeda, maka juallah sesuka kalian, selama dilakukan dari tangan ke tangan (kontan)"31.

Contoh: membeli emas dengan uang, membeli emas dengan perak, membeli perak dengan uang.

Dhabit ketiga: Semua komoditi yang berbeda 'illat-nya, maka dalam transaksinya tidak disyaratkan apa-apa, tidak disyaratkan sama nilainya ataupun al- hulul wa altaqā bud (langsung serah terima di majelis akad atau kontan). Contoh: membeli kurma dengan uang, membeli beras dengan uang. Dhabit keempat: transaksi komoditi ribawi dengan non-komoditi ribawi, atau transaksi suatu jaminan dengan komoditi ribawi,

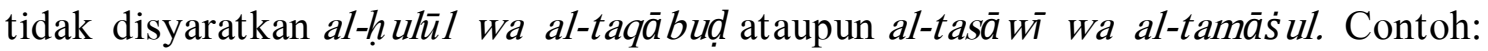
Membeli baju dengan emas, membeli buku dengan perak, membeli mobil dengan uang. Termasuk juga dalam kaidah ini transaksi non-komoditi ribawi dengan non-komoditi

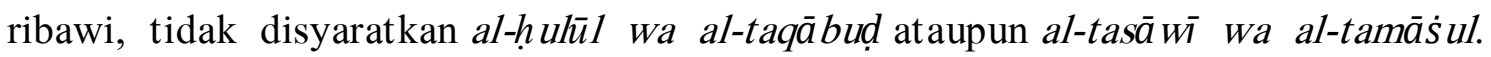
Contoh: membeli baju dengan buku, membeli mobil dengan rumah, membeli laptop dengan handphone.

\section{Akad Jual Beli Emas/Murabahah Emas}

Akad jual beli emas/murabahah emas dibolehkan, selama dilakukan secara tunai. Oleh karena itu, jika Pegadaian hanya menyediakan emas batangan ukuran lima gram, maka nasabah yang ingin membeli emas, harus menyediakan uang yang cukup untuk menebus emas lima gram itu. Artinya, emas lima gram ini harus dibeli secara tunai. Jika nasabah tidak memiliki dana yang cukup senilai emas lima gram, bisa dipastikan dia akan membeli emas lima gram itu secara tidak tunai (dicicil). Terlebih pihak Pegadaian

\footnotetext{
${ }^{30}$ Dhabit adalah batasan atau tolok ukur yang dijadikan bahan pertimbangan terhadap sesuatu hal.

${ }^{31}$ Muslim bin al-Hajjāj Abu al-Hasan al-Qusyairi al-Naisābūri, șah̄̄h Muslim (Bairut:Dār Ihyā alTurāś al-'Arabī, t.th.), h. 1121.
} 


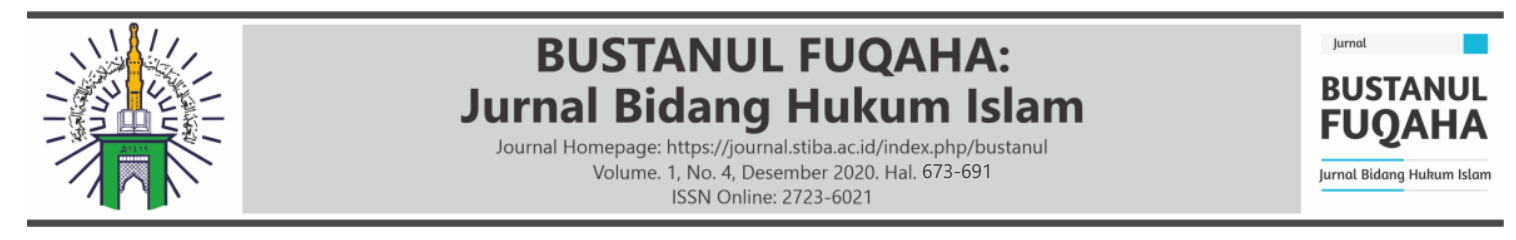

menerima cicilan senilai minimal emas 0,1 gram. Sebagai ilustrasi, Jika harga emas 500 ribu/gram, berarti nasabah yang ingin membeli emas secara tunai, dia harus memiliki dana 2,5 juta, sehingga 2,5 juta ditukar dengan emas lim gram secara tunai. Jika nasabah membayar dengan cara dicicil, misalnya 50 ribu/hari, berarti terjadi pertukaran emas dengan uang secara tidak tunai. Dengan demikian, hal ini hukumnya dilarang, termasuk "riba nasì'ah".

Namun, dalam kesempatan yang lain, Dewan Syariah Nasional (DSN) mengeluarkan fatwa yang membolehkan jual-beli emas secara tidak tunai yang berbunyi: "Jual beli emas secara tidak tunai, baik melalui jual beli biasa atau jual beli murabahah, hukumnya boleh (mubah, jaiz) selama emas tidak menjadi alat tukar yang resmi (uang)"32. Fatwa ini merujuk kepada pendapat lbnu Taimiyah dan Ibnu Qayyim yang membolehkan menukar emas perhiasan dengan dinar (uang emas) dengan cara tidak sama beratnya dan tidak tunai karena emas adalah perhiasan dan bukan mata uang, dengan demikian emas perhiasan telah keluar dari 'illat uang emas dinar, yaitu samaniyah. Maka emas perhiasan tak ubahnya barang dagangan yang boleh ditukar dengan mata uang emas (dinar) dengan cara tidak tunai dan tidak sama beratnya.

Ibnu Taimiyah rahimahullāh berkata: "Emas dan perak dalam bentuk perhiasan yang ada unsur buatan manusia tidak disyaratkan menjualnya dengan yang sejenis (dinar/dirham) sama beratnya, karena nilai tambah pembuatan emas perhiasan. Jual beli boleh dilakukan tunai ataupun tidak tunai, selama perhiasan emas dan perak tersebut tidak dimaksudkan sebagai saman (harga, uang)"33. Ibnu Qayyim rahimahullāh memperkuat pendapat tersebut dengan memberikan argumen bahwa perhiasan emas dan perak telah keluar dari fungsi emas dinar dan perak dirham sebagai alat tukar menjadi barang dagangan biasa ${ }^{34}$. Dari kedua pendapat ulama tersebut, tampak bahwa dewasa ini emas telah beralih fungsi dari alat tukar menjadi barang dagangan (komoditi).

Dialektika tentang 'illat emas tetap menjadi perdebatan di kalangan ulama kontemporer, semisal Erwandi Tarmizi memberikan beberapa tanggapan terkait hal ini, yakni: ${ }^{35}$ Pertama, dalam istilah ilmu usul fikih cara DSN mengambil dalil dinamakan dengan takhrīj, yaitu menganalogikan bolehnya murabahah emas dengan pendapat yang membolehkan menjual perhiasan emas dengan uang emas secara tidak tunai. Agar hukum yang di-takhrīj (dianalogikan) menjadi kuat maka disyaratkan bahwa pendapat almukharraj minhu (dalam hal ini bolehnya menjual perhiasan emas dengan uang emas dengan cara tidak tunai) haruslah pendapat yang rajih (kuat).

\footnotetext{
${ }^{32}$ Fatwa Dewan Syariah Nasional Nomor: 77/DSN-MUI/V/2010 Tentang Jual-Beli Emas Secara Tidak Tunai, h. 11.

33، Ala' al-Dīn Abu al-Hasan al-Ba'lī al-Dimasyqī, al-Ikhtīarat al-Fiqhīah min Fatawa Syaikh Ibn Taimīah, (al-Qāhirah: Dār al- Istiqāmah, 2005), h. 146.

${ }^{34}$ Muhammad bin Abī Bakr bin Ayyūb bin Sa'd Syamsu al-Dīn bin Qayyim al-jawziyah, I'lām alMuwaqqi în 'an Rabbil 'ālamīn, (Cet. I; Bairut: Dār al-Kutub al-'ilmiyah, 1991), h. 108.

${ }^{35}$ Erwandi Tarmizi, Harta Haram Muamalat Kontmporer, h. 560.
} 


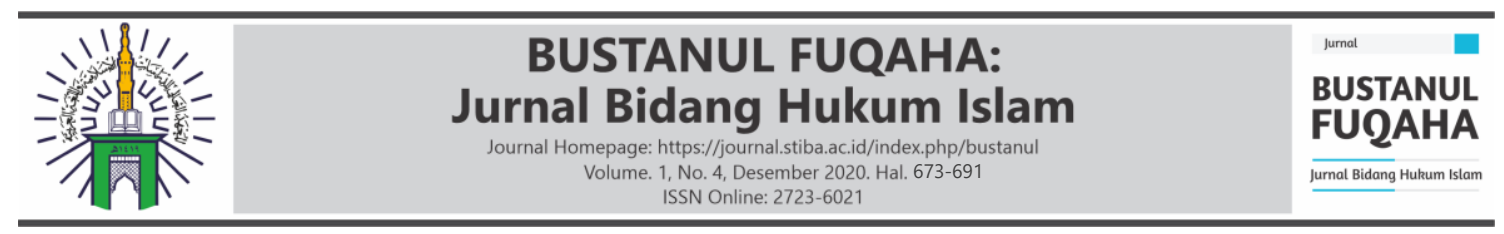

Namun, sayang persyaratan ini tidak terpenuhi karena pendapat ini sangat lemah dan bertentangan dengan pendapat mayoritas ulama bahkan beberapa ulama menukil bahwa pendapat tersebut bertentangan dengan ijmak. Ibnu Hubairah (wafat th. $560 \mathrm{H}$ ) berkata: "Umat Islam telah sepakat bahwa tidak boleh menukar emas dengan emas, atau perak dengan perak baik yang masih berbentuk bahan baku, berbentuk mata uang, ataupun berbentuk perhiasan dengan corak secara tidak tunai dan tidak sama beratnya. Ini merupakan riba nasiah dan riba fadl. Dan umat Islam juga sepakat bahwa boleh menukar emas dengan perak dengan ukuran yang berbeda akan tetapi haram dilakukan dengan cara tidak tunai"’36. Oleh karena pendapat ini terlalu lemah, maka Majma'AlFiqh Al Islāmī (divisi fikih OKI) tidak menganggap pendapat ini dalam muktamar di Abu Dhabi pada tahun 1995 dengan keputusan yang berbunyi, "Menekankan kembali pendapat seluruh para ahli fikih yang melarang menukar emas perhiasan dengan yang tidak perhiasan dengan ukuran yang tidak sama".

Kedua, setelah mengetahui bahwa pendapat ini syadz(keliru) dikarenakan jelasjelas bertentangan dengan hadis yang mewajibkan menukar emas dengan emas dengan cara tunai. Juga hadis tersebut mutlak melarang menukar emas dengan emas dengan cara tidak tunai (baik emas perhiasan ataupun emas sebagai mata uang) dan tidak ada satupun dalil yang men-taqyīd (mengikat) kemutlakan emas tersebut, maka mengkhususkan larangan hanya untuk emas sebagai mata uang termasuk men-taqyid dengan tanpa dalil. Adapun dalil bahwa dengan adanya unsur pembuatan manusia menjadikan emas perhiasan keluar dari emas yang dimaksud pada masa Nabi șallallāhu 'alaihi wasallam sebagai alat tukar tidak dapat dibenarkan, karena emas yang menjadi alat tukar di masa Nabi saw. pun terdapat unsur pembuatan manusia dalam bentuk ukiran gambar, ornamen, dan tulisan.

Ketiga, kemudian dalil bahwa 'illat riba emas adalah śmaniyah (uang sebagai alat tukar) dan bila 'illat ini hilang dari emas karena sekarang emas bukan lagi sebagai alat tukar telah diganti dengan uang kartal maka emas dianggap sama dengan barang lainnya boleh ditukar dengan uang kartal dengan cara tidak tunai, sangat lemah dari tinjauan kaidah usul fikih karena persyaratan keabsahan sebuah 'illat mustanbatah bahwa 'illat tersebut tidak boleh menafikan 'illat asalnya. Dengan demikian, 'illat samaniyah yang sifatnya ijtihad para ulama tidak boleh menafikan 'illat emas yang dijelaskan Nabi secara tekstual. ${ }^{37}$ Lebih tegas lagi syaikh Ibnu Bayyah (ulama senior ketua majelis fatwa Eropa) menjelaskan dalam bukunya Maqașid Al Mu'āmalat, 'illat mustanbatah ('illat yang berasal dari ijtihad para ulama) tidak mungkin dapat membatalkan hukum yang di-'illatinya ketika 'illat-nya tidak terdapat pada hukum tersebut. Seperti 'illat śamaniyah pada emas dan perak ketika emas dan perak tidak lagi

\footnotetext{
${ }^{36}$ Yahya bin Muhammad bin hubairah al-Zuhl̄̄ al-Syaibānī, Ikhtilāf al-Aimmah al- 'ulamā, (Cet. I; Beirut: Dār al-Kutub al-'Ilmīyah, 2002), h.358.

${ }^{37}$ Abū 'Abdillāh Badaruddin Muhammad bin 'Abdillāh bin Buhādir al-Zarkasȳ̄, al-Bahr al-Muhīth fi Ușūl al-Fiqh, (Cet.I; Dār al-Kutubī, 1994), h. 193.
} 


\begin{tabular}{|c|c|c|}
\hline 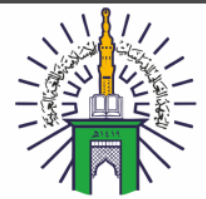 & 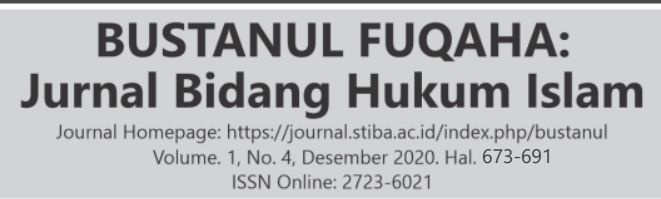 & $\begin{array}{l}\text { jurnal } \\
\text { BUSTANUL } \\
\text { FUQAHA } \\
\text { Jumal Bidang tukum slam }\end{array}$ \\
\hline
\end{tabular}

sebagai alat tukar maka ketiadaan 'illat samaniyah pada emas dan perak tidak berpengaruh pada hukum riba emas dan perak. Karena riba emas dan perak di-nașkan oleh pembuat syariat (Nabi) maka tidak mungkin dibatalkan oleh illat mustanbatah. Juga dari tinjauan maqāṣid al-syari ah yang lain maqșad larangan menukar emas dan perak secara tidak tunai merupakan maqsad utama dan sangat jelas maka tidak mungkin dinafikan oleh maqsad pengikut (yaitu: śamaniyah) yang derajatnya zannī.

Keempat, andai pendapat Ibnu Taimiyah rahimahullāh kita anggap sebagai pendapat yang kuat, tetap juga tidak dapat dibenarkan menarik hukum boleh menukar uang kartal dengan emas seperti yang dipraktikkan oleh Bank Syariah, karena lbnu Taimiyah tidak membolehkan secara mutlak beliau mengikatnya selama emas tidak dimaksudkan sebagai śamaniyah (alat tukar, harga). Persyaratan ini tidak terpenuhi pada praktik Bank Syariah karena emas yang dijual secara murabahah oleh pihak bank bukanlah emas perhiasan akan tetapi emas batang yang memang dimaksudkan sebagai investasi, sedangkan menjadikan emas sebagai investasi juga merupakan salah satu fungsi uang.

Kelima, fatwa DSN yang membolehkan jual beli emas tidak tunai membuka celah menghalalkan riba jāhiliyah dalam bentuk pertambahan nilai utang. Keenam, fatwa DSN yang membolehkan jual beli emas secara tidak tunai bertentangan dengan Panduan Perbankan Syariah Internasional yang dibuat oleh AAOIFI (The Accounting and Auditing Organization for Islamic Financial Institutions) yang menyatakan dalam bab: Al Murabahah lil Amir Biqtsyira', No. 2/2/6, bahwasanya murabahah tidak tunai tidak boleh dilakukan pada objek emas, perak atau mata uang.

\section{KESIMPULAN}

Dari beberapa analisis yang telah dipaparkan pada bab-bab sebelumnya, maka dapat ditarik kesimpulan, yaitu:

1. Mengenai praktik pihak Pegadaian Syariah Cabang Pinrang bermaksud memberikan kemudahan bagi nasabah yang ingin memulai untuk berivestasi emas dan dengan harga yang terjangkau. Pegadaian Syariah Cabang Pinrang menawarkan produk berupa Tabungan Emas, yaitu layanan jual beli emas dengan fasilitas titipan. Dalam hal ini nasabah selaku pembeli menabung (membeli) emas ke Pegadaian Syariah selaku penjual. Kemudian jumlah uang yang ditabung oleh nasabah akan dikonversikan ke dalam bentuk gram emas oleh Pegadaian sesuai dengan jumlah nominal yang di tabung dan tentunya sesuai dengan harga jual beli emas pada hari itu. Dari proses pembelian tersebut, nasabah akan mendapatkan beberapa gram emas, akan tetapi emas tersebut tidak diserahkan langsung saat transaksi melainkan saldo gram emas dititip di Pegadaian. 


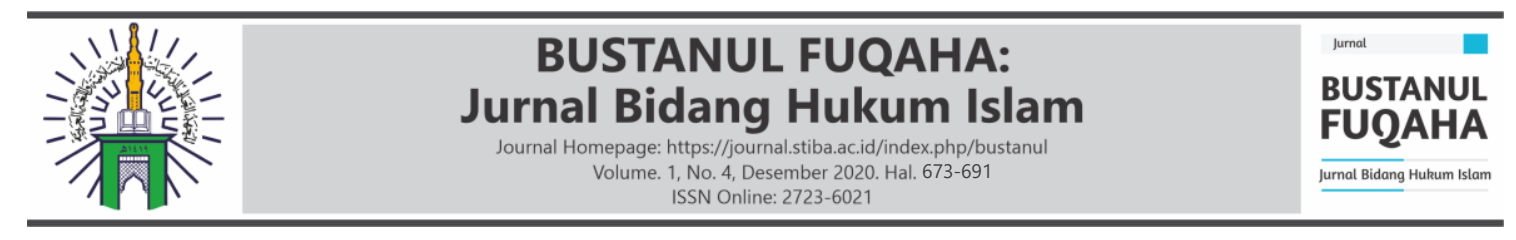

2. Proses pencairan (menjual) emas dilakukan dengan dua cara yaitu dengan jual kembali jika menghendaki uang tunai dan pencetakan jika menghendaki dalam bentuk emas batangan.

3. Tinjauan hukum Islam terhadap jual beli emas pada sistem Tabungan Emas Pegadaian Syariah Cabang Pinrang dalam hal ini terdapat dua pendapat mengenai jual beli emas/murabahah pada sistem Tabungan Emas, yaitu: Pendapat pertama mengatakan tidak boleh, pendapat ini didukung oleh pendapat mayoritas ahli fikih, dari mazhab Hanafi, Maliki, Syafii, dan Hambali (sebagian dari Syafi'iyyah dan Malikiyyah dengan dalil bahwa emas adalah alat pembayaran/uang) yang tidak boleh dipertukarkan secara angsuran, karena itu menyebabkan riba. Oleh karena itu, jual beli emas/murabahah harus dilakukan secara tunai pada saat akad terjadi. Sedangkan pendapat kedua mengatakan boleh, pendapat ini didukung oleh Dewan Syariah Nasional MUI dan ulama kontemporer yang lain dengan berdalil melalui pendapat Ibnu Taimiyah dan Ibnu Qayyim yang menganggap bahwa jual beli emas/murabahah emas boleh dilakukan baik secara tunai maupun kredit asalkan keduanya tidak dimaksudkan sebagai śaman (harga) melainkan sil'ah (barang).

4. Peneliti lebih condong ke pendapat yang pertama yaitu pendapat para ahli fikih yang menganggap bahwa emas dan perak adalah śamaniyah (alat tukar, uang) yang dalam akadnya harus dilakukan secara tunai.

\section{DAFTAR PUSTAKA}

'Abdillāh, Nu'mān bin Mahmūd bin. (1981). Jilāu al-'Aynayni fī muhākamati alAhmadaini. t.t: Matba' ah al-MadanI

Al-Baihaqī, Ab̄̄ Bakar Ahmad bin al-Husain bin 'Alī. (2003). Sunan al-Kubrā (Cet. III). Beirut: Dār al-Kutub al-'Ilmīyah).

Al-Bukhārī, Abū 'Abdillāh Muhammad bin Ismā'īl bin Ibrāhīm bin al-Mugīrāh al-Ju'fī. (1422 H). Sohīh al-Bukhārī, (Cet. I). Madinah: Dār tūk al-Najah.

Al-Dimasyqī, 'Ala' al-Dīn Abu al-Hasan al-Ba'lī. (2005). al-Ikhtīarat al-Fiqhīah min Fatawa Syaikh Ibn Taimīah. al-Qāhirah: Dār al- Istiqāmah.

Al-Jawziyah, Muhammad bin Ab̄̄ Bakr bin Ayyūb bin Sa'd Syamsu al-Dīn bin Qayyim. (1991). I'lām al-Muwaqqi ìn 'an Rabbil 'à lamīn (Cet. I). Bairut: Dār al-Kutub al-'ilmiyah.

Al- Mawardi. (1999). al- Hawi al- Kabir fi fiqh mazhab al-Imam al- Syafi'i, (Cet: I) Bairut: Dar al- Kutub al- 'Ilmiyyah,

Al-Naisābūri, Muslim bin al-Hajjāj Abu al-Hasan al-Qusyairi. (t.th). Sahīh Muslim Bairut: Dār Ihyā al-Turās al-'Arabī,.

Al-Syaibān̄̄, Yahya bin Muhammad bin hubairah al-Zuhlī. (2002). Ikhtilā f al-Aimmah al- ‘ulamā, (Cet. I; Beirut: Dār al-Kutub al-'Ilmīyah,). 


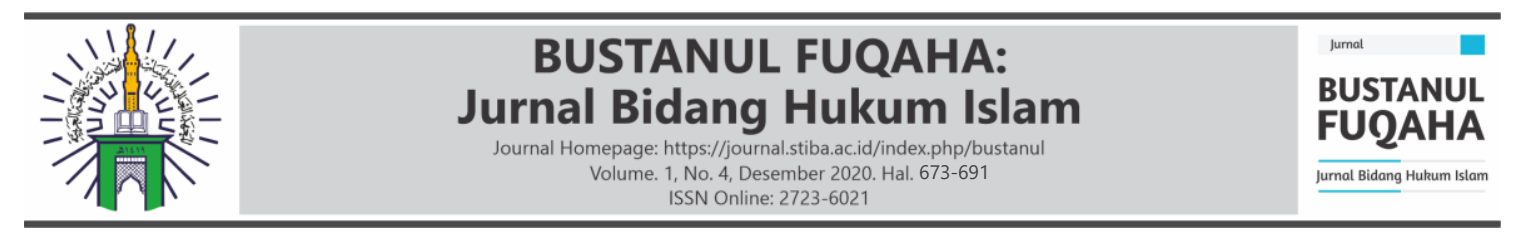

Al-'Uṡaimin, Muhammad bin șāleh. (1979). Fatawa Nūrun 'Alā al-Darb. Cet. I; Riyaḍ: Mu'assasah Al-Syaikh Ibnu 'Uśaimin al-khairīah.

Al-Zarkasȳ̄, Abū 'Abdillāh Badaruddin Muhammad bin 'Abdillāh bin Buhādir. (1994). al-Bahr al-Muhìth fì Ușūl al-Fiqh Cet.I. Dār al-Kutubī,.

Anggraini, Y. (2017). Tinjauan hukum Ilam terhadap jual beli emas pada sistem tabungan emas pegadaian syariah cabang Cakranegara Mataram (Doctoral dissertation, Universitas Islam Negeri Mataram).

Arikunto, S. (2013). Prosedur Penelitian, Suatu Pendekatan Praktik, Cet. XV; Jakarta: PT Rineka Cipta.

Asriani. (2015). "Investasi Emas Syariah Dalam Perpektif Hukum Islam." Al'Adalah Vol.7, no.4, h.855-866.

Fatwa Dewan Syariah Nasional, Nomor: 77/DSN-MUI/V/2010 Tentang Jual-Beli Emas Secara Tidak Tunai.

Iskandar, A., \& Aqbar, K. (2019). Kedudukan Ilmu Ekonomi Islam di Antara Ilmu Ekonomi dan Fikih Muamalah: Analisis Problematika Epistemologis. NUKHBATUL'ULUM: Jurnal Bidang Kajian Islam Vol.5, No.2

Kementrian Agama RI. (2017). al-Qur'ān dan Terjemahnya. Bandung: Cordoba.

Mangani, K. S. (2009). “Bank Dan Lembaga Keuangan Lain. Jakarta: Penerbit Erlangga.

Muhammad bin 'Abdillah al- Kharsyi al- Maliki,. (T.th). Syarh Mukhtasar Khalil. Bairut: Dar al- Fikr littiba'ah.

Riziqitaniyah, S. N. (2019). "Tinjauan Hukum Islam Terhadap Produk Tabungan Emas di Pegadaian Syariah dan Pegadaian Konvensional (studi komperatif)", Skripsi, (Banten: Fakultas Syariah Universitas Islam Negeri Sultan Maulana Hasanuddin Banten).

Semiawan C. R. (2010). Metode Penelitian Kualitatif Jenis, Karasteristik, dan Keunggulannya. Cikarang: Grasindo.

Tarmizi, E. (2012). Harta Haram Muamalat Kontemporer (Cet. I). Bogor: P.T. Berkat Mulia Insani.

Usman, M. H., Aswar, A., \& Irawan, A. W. (2020). Syariat Islam dan Kemaslahatan Manusia di Era New Normal pada Kegiataan Keagamaan dan Pendidikan. FENOMENA, 12 (1), 89-106.

\section{Sumber Online:}

https://www.Pegadaian.co.id/produk/tabungan-emas (Diakses tanggal 14 April 2020)

https://www.pegadaian.co.id/produk/tabungan-emas (Diakses tanggal 23 Desember 2020)

\section{Informan Wawancara:}

Annisha Resqia, Wawancara, Pinrang, 10-19 April 2020. 